\title{
Effect of Varieties, Phosphorus and Boron Fertilization on Sugar Beet Yield and its Quality \\ Fatma A. Ghaly ${ }^{1}$; M. R. Abd-Hady ${ }^{2}$; A. S. Abd-Elhamied ${ }^{1}$ and M. E. Abu. Mosallm ${ }^{1}$ \\ ${ }^{1}$ Soil Sci. Dept., Fac. of Agric., Damietta Univ., Egypt \\ ${ }^{2}$ Soils, Water and Environment Res. Inst.,AGRIC.REC.CENTER,EGYPT
}

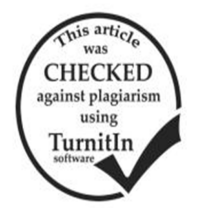

\section{ABSTRACT}

The present study was conducted at a private Farm, Kalabsho, Belqas Center, Dakahlia Governorate during the two successive seasons of 2014/2015 and 2015/2016. This investigation was layout to find the effect of Cultivars (Gloria and Diamond), phosphorus (0, $12,24,36,48 \mathrm{~kg} \mathrm{P}_{2} \mathrm{O}_{5} \mathrm{fed}^{-1}$ as a mono-super phosphate) and boron ( $0,0.750$ and $\left.1.125 \mathrm{~kg}^{\text {Borax fed }}{ }^{-1}\right)$ and their interaction on yield, yield components and sucrose of sugar beet plants (Beta vulgaris, L.). A split-split-plot design with four replicates was done. Experimental unit (sub-sub plot) was $10.5 \mathrm{~m}^{2}(1 / 400 / \mathrm{fed})$ " $3 \times 3.5 \mathrm{~m}$ " including 5 ridges each of $60 \mathrm{~cm}$ apart and 3.5 long. The importance findings can be summarized as follows:The highest values of top yield could be obtained from diamond in the $1^{\text {st }}$ season and Gloria Cultivar in the $2^{\text {nd }}$ one. The optimum phosphorus fertilizer treatments were $48 \mathrm{~kg} \mathrm{P}_{2} \mathrm{O}_{5} \mathrm{fed}^{-1}$, thereby it caused a significant increase and the greatest values of top yield. Moreover, the response of sugar beet top yield to the interaction varietal effects $\mathrm{X}$ boron fertilizer levels was significant in the two seasons. Phosphorus at a rate of $48 \mathrm{~kg} \mathrm{P}_{2} \mathrm{O}_{5}$ was the best treatment among other phosphorus treatments, which resulted in the maximum root yield in the $1^{\text {st }}$ and $2^{\text {nd }}$ seasons. Furthermore, control treatment (without addition) recorded the lowest mean in the $1^{\text {st }}$ and $2^{\text {nd }}$ seasons, respectively. With expecting the impact of boron fertilizer effects on root yield, increasing its levels from 0 to $1.125 \mathrm{~kg} \mathrm{H}_{3} \mathrm{PO}_{4} \mathrm{fed}^{-1}$ tended to increase root yield in the two growing seasons. Generally, the highest total yield achieved from Gloria cultivar with mean $30.72 \mathrm{Mg}_{\text {fed }}^{-1}$ while, Diamond cultivars recorded $28.44 \mathrm{Mg} \mathrm{fed}^{-1}$ in the first season. Meanwhile, in the second season the same trend were observed for cultivars Gloria which surpassed cultivars Diamond.cultivars of beets, Phosphorus showed a significant increase in sucrose \% and increasing boron fertilizer levels from 0 to 0.750 and $1.125 \mathrm{~kg}$ Borax/fed tended to increase sucrose \% from 16.82 to 16.89 and 16.98 in the first season and 20.17, 20.23 and $20.30 \%$ in the second season, respectively. It could be concluded that all used treatments significantly affected on suger beet yield and its component. The interaction between Gloria cultivars, phosphorus fertilizer at the rate of $48 \mathrm{~kg} \mathrm{P}_{2} \mathrm{O}_{5}$ fed $^{-1}$, boron at the rate of $1.125 \mathrm{~kg} \mathrm{fed}^{-1}$ recorded the best in all used treatments.

Keywords: sugar beet, phosphorus , boron, sucrose \%, total yield

\section{INTRODUCTION}

Improving sugar beet productivity is a serious demand to meet sugar consumption or at least to decrease the Egyptian gap between production and consumption. In Egypt, sowing sugar beet usually takes place during the period extended from Sept. to Nov.. Many investigators showed the effect of phosphorus and boron fertilizer levels on growth, yields and quality characteristics of sugar beet Cultivars. Shalaby et al. (2011) reported that Kawemira variety significantly surpassed on the others in root fresh weight/plant, sucrose and roots and yields/fed. Ali et al. (2012) reported that Samba variety had the highest values of root and sugar yields /fed as will as sucrose and purity percentages. Mehanna (2017) declared that Samba variety was the superior in root characters i.e. length, and diameter and yield of roots and sugar/fed.

Besides, phosphorus is a major element in plant nutrition that is the most important component of nucleic acids and lipids and is important in the production and transport of sugars in sugar beet plant. Phosphorus is effectiveness in sugar beet early root development. It is a critical macronutrient required for numerous functions in the plant, including energy generation, nucleic acid synthesis, photosynthesis, glycolysis, respiration, carbohydrate metabolism and nitrogen fixation.

Ismail et al. (2007) and Ouda (2007) reported that fresh and dry weights, leaf area index and root and sugar yields, as well as sucrose \% and sugar loss to molasses were increased as $\mathrm{P}$ rate increased up to $30 \mathrm{~kg} \mathrm{P}_{2} \mathrm{O}_{5} \mathrm{fed}^{-1}$.

Abdou et al. (2008) stated that increasing phosphorus fertilizer levels from 0.0 up to $30 \mathrm{~kg} \mathrm{P}_{2} \mathrm{O}_{5} \mathrm{fed}^{-1}$, markedly increased root weight by 10.80 and $10.82 \%$, root yield $\left(\mathrm{Mg} \mathrm{fed}^{-1}\right)$ by 17.56 and $17.72 \%$ and sugar yield $(\mathrm{Mg}$ fed $^{-1}$ ) by 29.31 and $29.52 \%$ in the first and second seasons, respectively. Marinković et al. (2008) showed that increasing $\mathrm{P}_{2} \mathrm{O}_{5}$ from 50 to 100 and $150 \mathrm{~kg} \mathrm{ha}^{-1}$ resulted in marked increases in root and sugar yields/ha. Seadh (2012) stated that application of $30 \mathrm{~kg} \mathrm{P}_{2} \mathrm{O}_{5} \mathrm{fed}^{-1}$, produced the highest values of growth characters and the highest values of the root, top and sugar yields $\mathrm{fed}^{-1}$, in both seasons. Abdou et al. (2014) found that adding $31.0 \mathrm{~kg} \mathrm{P}_{2} \mathrm{O}_{5}$ fed $^{-}$ ${ }^{1}$ and thinning at the age of 20 days was the suitable recommendation to maximize sugar beet root yield and quality under the environmental conditions of Dakahlia Governorate. Hussain et al. (2014) declared that the addition of P1 (the first rate) and P2 (the second rate) increased beet yield by 37 and $47 \%$ over control. The shoot phosphorus (mmol kg $\mathrm{mg}^{-1}$ was achieved as 55.2, 73.6 and 84.3 at $\mathrm{P} 0, \mathrm{P} 1$ and $\mathrm{P} 2$, respectively.

Boron is by far the most important of the trace elements needed sugar beet because, without an adequate supply, the yield and quality of roots are very depressed. Soil application, as well as, a foliar spray of boron is equally effective, hence the fresh root weight, sucrose \%, root and top yields significantly increased by increasing boron levels. Armin and Asgharipour (2012) reported that the highest root yield and sucrose concentration was obtained by spraying with $12 \%$ boric acid. Soliman et al. (2014) showed that boron as a foliar application significant responses in the two seasons with respect to growth characters of sugar beet. Increased boron foliar application from 0 to $0.4 \mathrm{~g} \mathrm{~L}^{-1}$. increasing growth characters of sugar beet at the first and second seasons. Application of boron spray exerted a significant increase in sugar, juice purity and crude protein percentage. Mekdad (2015) reported that Application of P1 and P 2 ppm boron significantly improved root yield and its attributes, percentage of gross and white sugar. On contrarily $\mathrm{Na}, \mathrm{K}, \alpha$-amino $\mathrm{N}$, loss sugar percentages, harvest index and loss sugar yield were decreased. Maximum root, top, sugar yield $\mathrm{fed}^{-1}$ and root quality was produced by 140 (N2) $\mathrm{kg} \mathrm{N} / \mathrm{fed}$ and 120 and /or 150 ppm boron. 
The present investigation aimed study the effect of two Cultivars( Gloria and Diamond ), phosphorus(0, 12, 24,36 and $48 \mathrm{~kg} \mathrm{P}_{2} \mathrm{O}_{5}$ fed $^{-1}$ as a mono-super phosphate) and boron $\left(0.0 .750\right.$ and $1.125 \mathrm{~kg}$ Borax fed $\left.^{-1}\right)$ and their interaction on yield, yield components and quality of sugar beet

\section{MATERIALS AND METHODS}

The present investigation was conducted at aprivate Farm, Kalabsho, Belqas Center, Dakahlia Governorate during seasons of 2014/2015 and 2015/2016. This study was layout to find the effect of cultivars (Gloria and Diamond), phosphorus and boron effects and their interaction on yield, yield components and quality of sugar beet plants (Beta vulgaris, L.). The cultivars were introduced from Dakahlia Company for sugar.

Experimental design

A spli-split plot design with four replicates was used. The main plots were assigned for the following cultivars i.e, Gloria and Diamond. The sub-plot was devoted to the phosphorus fertilizer rates in the form of mono-super phosphate $\left(15.5 \% \quad \mathrm{P}_{2} \mathrm{O}_{5}\right)$ were used in one time addition after planting. In addition, the sub-sub plots including spraying boron in the form of Borax in two equal portions : $1.125 \mathrm{~kg} \mathrm{fed}^{-1}$ and $0.750 \mathrm{~kg} \mathrm{fed}^{-1}$.

The sugar beet seeds were sown on $26^{\text {th }}$ August and $23^{\text {rd }}$ August in the two seasons, respectively. Sugar beet seeds were hand sown (dry sowing method) on one side of the ridge in hills $20 \mathrm{~cm}$ apart at the rate of 3-5 balls/hill. The plots were irrigated immediately after sowing. After one month, plants were thinned to two plants/hill and singled to one plant/hill after 30 days from sowing. The recommended agricultural practices were kept in the same normally practiced according to the recommendation of ARC. The experimental unit (sub-sub plot) was $10.5 \mathrm{~m}^{2}$ " $3 \times 3.5 \mathrm{~m}$ " including five ridges each of $60 \mathrm{~cm}$ apart and 3.5 long. The preceding summer crop was watermelon in both seasons. Some Pphysical and chemical properties of the field experimental samples are shown in Table (1).

Table 1. Some physical and chemical properties of the experimental soil.

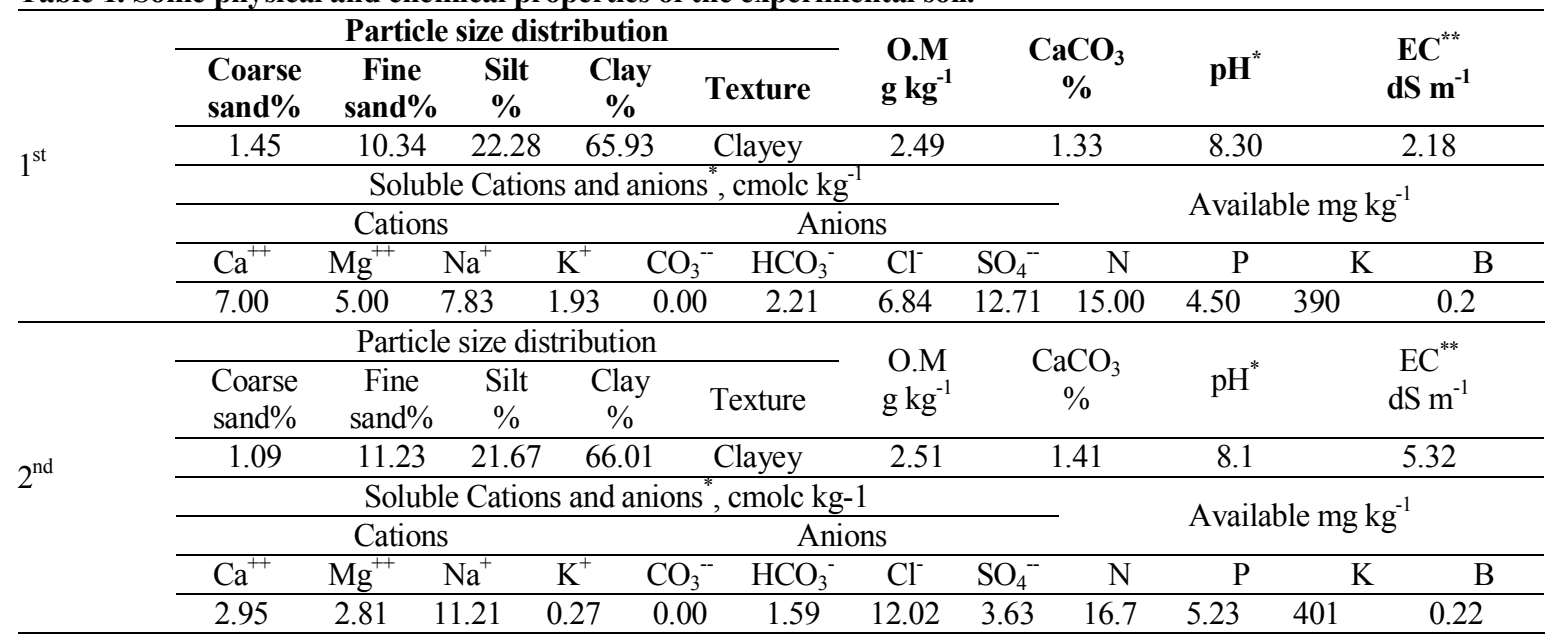

The soil of the experiment was clay in texture. Soil samples were taken from 15 to $30 \mathrm{~cm}$ depth in the experimental sites before soil preparation to measure the important chemical and physical properties of soil according to Black (1965).

Yield components:

At maturity (210 days from planting), five plants were chosen at random from the central of ridges of each sub-sub plot to determine the following characters:

1. Root fresh weight $\left(\mathrm{Mg} \mathrm{fed}^{-1}\right)$

2. Top fresh weight $\left(\mathrm{Mg} \mathrm{fed}^{-1}\right)$

3. Root diameter $(\mathrm{cm})$

Quality: Sucrose percentage (\%): It was determined Polarimetrically on lead acetate extract of fresh macerated roots according to the method of Le-Docte (1927).

Yield $\left(\mathbf{M g ~ f e d ~}^{-1}\right)$ : At harvest i.e. 210 days from planting, plants of the three ridges were pulled up and yield were estimated.

\section{Statistical analysis}

All data were statistically analyzed according to the technique of analysis, variance (ANOVA), the least significant difference and was used to compare the differences between the means of studied treatments values according to methods described by Gomez and Gomez (1984). All measured investigations were performed utilizing a examination fluctuation procedure by method of CoSTATE PC programming.

\section{RESULTS AND DISCUSSION}

Top fresh weight $\left(\mathrm{Mg} \mathrm{fed}^{-1}\right)$ :

Data related to the effect of cultivars, phosphorus, boron and their interactions on top yield $\left(\mathrm{Mg} \mathrm{fed}^{-1}\right)$ during 2014/2015 and 2015/2016 seasons are shown in Table 2

Cultivars effects:

Cultivars had a significant effect on top yield $(\mathrm{Mg}$ $\mathrm{fed}^{-1}$ ) during the two growing seasons of study . By Dwelling obtained data, the highest values of top yield (9.398 and $10.042 \mathrm{Mg} \mathrm{fed}^{-1}$ ) in the first and second seasons, respectively) could be obtained from diamond in the $1^{\text {st }}$ season and Gloria in the second season. On the contrary of that, the lowest means in this terms (6.777 and $9.807 \mathrm{Mg} \mathrm{fed}^{-1}$ ) in the first and second seasons, respectively) were obtained from Gloria cultivars in the $1^{\text {st }}$ season and Diamond cultivars in the second one. The differences between the two cultivars in the studied characters may be due to hereditary differences. This result 
was in line with those reported by, Shalaby (1998), Ali (2000) and Shalaby et al. (2011).

Effect of phosphorus fertilizer:

Phosphorus treatments caused a significant increase in top yield per feddan. The optimum phosphorus fertilizer treatments were $48 \mathrm{~kg} \mathrm{P}_{2} \mathrm{O}_{5}$, thereby it caused significant increase and the greatest values of top yield, which registered data were( 8.926 and $12.412 \mathrm{Mg} \mathrm{fed}^{-1}$ ) in the first and second seasons, respectively (Table 2). However, $36 \mathrm{~kg} \mathrm{P}_{2} \mathrm{O}_{5}$ treatment came in the second rank after the aforementioned treatment and then the control treatment recorded the lowest values in the two seasons. The effect of phosphorus which stimulates vegetative growth and consequently top yield per feddan. A positive association of phosphorus treatments for top yield per feddan has been reported by Abo El-Goud (2000) and Abdou et al. (2008).

Table 2. Effect of Cultivars, phosphorus and boron fertilizers on top fresh weight of sugarbeet.

\begin{tabular}{|c|c|c|}
\hline \multirow{2}{*}{$\begin{array}{l}\text { Characters } \\
\text { Treatments }\end{array}$} & \multicolumn{2}{|c|}{ Top fresh weight $\left(\mathrm{Mg} \mathrm{fed}^{-1}\right)$} \\
\hline & $2014 / 2015$ & $2015 / 2016$ \\
\hline \multicolumn{3}{|l|}{ 1. Cultivar effects: } \\
\hline Diamond & 9.398 & 9.807 \\
\hline Galoria & 6.777 & 10.042 \\
\hline F-test & $* *$ & $* *$ \\
\hline \multicolumn{3}{|c|}{ 2. Phosphorus effects $\left(\mathrm{kg} \mathrm{P}_{2} \mathrm{O}_{5} \mathrm{fed}^{-1}\right)$} \\
\hline 0 & 6.816 & 7.197 \\
\hline 12 & 7.486 & 9.171 \\
\hline 24 & 8.323 & 10.017 \\
\hline 36 & 8.889 & 10.828 \\
\hline 48 & 8.926 & 12.412 \\
\hline F-test & $* *$ & $* *$ \\
\hline LSD 0.05 & 0.485 & 0.169 \\
\hline LSD 0.01 & 0.708 & 0.248 \\
\hline \multicolumn{3}{|c|}{ 3. Boron effects $\left(\mathrm{g} \mathrm{fed}^{-1}\right)$} \\
\hline 0 & 7.712 & 9.435 \\
\hline 750 & 8.190 & 9.919 \\
\hline 1125 & 8.362 & 10.516 \\
\hline F-test & $*$ & $* *$ \\
\hline LSD 0.05 & 0.307 & 0.107 \\
\hline LSD 0.01 & 0.448 & 0.157 \\
\hline \multicolumn{3}{|l|}{ 4. Interaction effects } \\
\hline $\mathrm{VxP}$ & NS & NS \\
\hline VXB & NS & NS \\
\hline PXB & NS & $* *$ \\
\hline V X P XB & NS & NS \\
\hline
\end{tabular}

\section{Effect of boron fertilizer levels:}

Surpassing boron fertilizer levels from 0 to 1.125 $\mathrm{kg}$ in the second season tended to increase top yield from 9.435 to $10.516 \mathrm{Mg} \mathrm{fed}^{-1}$ while in the first season the third level recorded the highest meanwhile the control treatment ranked the second. A similar trend was established by Soliman et al. (2014) who they reported that increasing boron foliar application from 0 to $0.4 \mathrm{~g}$ per litter increased growth characters of sugar beet at the first and second seasons, respectively. Also, Dewedar et al. (2015) reported the same trend. As shown from tabulated data in Table 2, phosphorus and boron combination levels exhibited no remarkable differences on top yield $\left(\mathrm{Mg} \mathrm{fed}^{-1}\right)$ in the first season. On the other hand, the interaction effects had a significant effects except cultivars* Phosphorus* boron.

The response of top yield to the interaction between phosphorus and boron treatments was significant in the second season (Table3). It can be considered the highest values of top yield were obtained due to the fifth level of phosphorus and the third levels of boron 9.55 and 13.20 $\mathrm{Mg} \mathrm{fed}^{-1}$ (in the first and second seasons, respectively) while, the lowest values 6.55 and $5.85 \mathrm{t} /$ fed recorded from control treatments for phosphorus and boron in the $1^{\text {st }}$ and $2^{\text {nd }}$ seasons, respectively.

The effect of the interaction among all factors under study on top yield was insignificant in the two seasons. It can be concluded that highest values of top yield (10.833and $13.533 \mathrm{Mg} \mathrm{fed}^{-1}$ in the first and second seasons, respectively) were produced from Gloria cultivars which treated with high levels of phosphorus and the highest dose of boron.

Table 3. Effect of phosphorus and boron treatments on top fresh weight $\left(\mathrm{Mg} \mathrm{fed}^{-1}\right)$

\begin{tabular}{|c|c|c|c|c|c|c|}
\hline \multirow{4}{*}{ 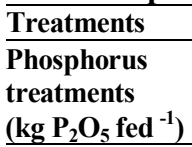 } & \multicolumn{6}{|c|}{ Boron effects $\left(\mathrm{g} \mathrm{fed}^{-1}\right)$} \\
\hline & \multicolumn{3}{|c|}{ 2014-2015 } & \multicolumn{3}{|c|}{ 2015-2016 } \\
\hline & $\mathbf{0}$ & 750 & 1125 & $\mathbf{0}$ & 750 & 1125 \\
\hline & g & g & $\mathbf{g}$ & $\mathbf{g}$ & g & $\mathbf{g}$ \\
\hline 0 & 6.55 & 6.87 & 7.03 & 5.85 & 7.43 & 8.30 \\
\hline 12 & 7.30 & 7.45 & 7.712 & 8.77 & 9.16 & 9.57 \\
\hline 24 & 8.17 & 8.33 & 8.46 & 9.77 & 9.96 & 10.31 \\
\hline 36 & 8.70 & 8.92 & 9.04 & 10.50 & 10.79 & 11.18 \\
\hline 48 & 7.83 & 9.39 & 9.55 & 11.80 & 12.22 & 13.20 \\
\hline$\overline{\text { F-tes }}$ & \multicolumn{3}{|c|}{ NS } & \multicolumn{3}{|c|}{$* *$} \\
\hline LSD at 0.05 & \multirow{2}{*}{\multicolumn{3}{|c|}{0.374}} & \multirow{2}{*}{\multicolumn{3}{|c|}{$\begin{array}{l}0.113 \\
0165\end{array}$}} \\
\hline LSD at 0.01 & & & & & & \\
\hline
\end{tabular}

Root yield $\left(\mathrm{Mg} \mathrm{fed}^{-1}\right)$ :

Means of root yield $\left(\mathrm{Mg} \mathrm{fed}^{-1}\right)$ as affected by cultivars e.g. Diamond and Gloria, phosphorus fertilizer levels, boron effect and their interactions at 90 and 150 days from planting during 2014/2015 and 2015/2016 are presented in Table 4.

\section{Effect of cultivars:}

Cultivars of exhibited insignificant effect on root yield in the two growing seasons. Generally, the highest root yield achieved from Gloria cultivars with mean 21.507 $\mathrm{Mg} \mathrm{fed}^{-1}$ while, Diamond cultivars recorded $21.337 \mathrm{Mg}$ $\mathrm{fed}^{-1}$ in the first season. Meanwhile, in the second season the same trend was observed for cultivars Gloria which surpassed cultivars Diamond. These increment in root yield might be due to the differences among sugar beet varieties under study refers to the variation in the genes makeup and their response to the environmental condition.

The differences among sugar beet varieties were found by Osman (2005), Azzazy et al. (2007), El-Sheikh et al. (2009) and Hanan Y. Mohamed and M.A.T. Yasin (2013)

\section{Effect of phosphorus fertilizer levels:}

The collected data in Table (4) show that there were remarkable significant differences among phosphorus treatments on root yield per feddan during the two growing seasons. Noteworthy, $48 \mathrm{~kg} \mathrm{P}_{2} \mathrm{O}_{5}$ was the best treatment among other phosphorus treatments, which resulted in the maximum root yield (28.909 and $34.154 \mathrm{Mg} \mathrm{fed}^{-1}$ ) in the first and second seasons, respectively. Furthermore, control 
treatment (without addition) recorded 15.272 and 17.590 $\mathrm{Mg} \mathrm{fed}^{-1}$ in the first and second seasons, respectively.

Addition of $36 \mathrm{~kg} \mathrm{P}_{2} \mathrm{O}_{5}$ ranked the second treatment for root yield which recorded 23.724 and $30.538\left(\mathrm{Mg} \mathrm{fed}^{-1}\right)$ in the two seasons. This effect of phosphorus treatments expressly may be ascribed to share in the bioactivities inside plants and increases the creating of carbohydrates like starch and sugars. Moreover, It helps in the division of plant cells and shares in forming ATP (Adenosine triphosphate). Similar results were obtained by Ismail and Abo El-Ghait (2004) and Abdou et al. (2008) who reported that increasing phosphorus fertilizer level from zero up to $30 \mathrm{~kg} \mathrm{P}_{2} \mathrm{O}_{5}$ fed $^{-1}$ markedly increased root weight $\mathrm{g} /$ plant.

Table 4. Effect of cultivars, phosphorus and boron treatments on root yield $\left(\mathrm{Mg} \mathrm{fed}^{-1}\right)$

\begin{tabular}{|c|c|c|}
\hline \multirow{2}{*}{$\begin{array}{l}\text { Characters } \\
\text { Treatments }\end{array}$} & \multicolumn{2}{|c|}{ Root yield $\mathrm{Mg}$ fed $^{-1}$} \\
\hline & $2014 / 2015$ & $2015 / 2016$ \\
\hline \multicolumn{3}{|c|}{ 1. cultivar effects } \\
\hline Diamond & 21.337 & 25.795 \\
\hline Galoria & 21.507 & 27.040 \\
\hline F-test & $* *$ & $* *$ \\
\hline \multicolumn{3}{|c|}{ 2. Phosphorus effects $\left(\mathrm{kg} \mathrm{P}_{2} \mathrm{O}_{5}\right.$ fed $\left.^{-1}\right)$} \\
\hline 0 & 15.272 & 17.590 \\
\hline 12 & 18.267 & 22.999 \\
\hline 24 & 20.938 & 26.807 \\
\hline 36 & 23.724 & 30.538 \\
\hline 48 & 28.909 & 34.154 \\
\hline F-test & $* *$ & $* *$ \\
\hline LSD 0.05 & 0.463 & 0.356 \\
\hline LSD 0.01 & 0.676 & 0.520 \\
\hline \multicolumn{3}{|c|}{ 3. Boron effects $\left(\mathrm{g} \mathrm{fed}^{-1}\right)$} \\
\hline 0 & 20.966 & 24.968 \\
\hline 750 & 21.347 & 26.405 \\
\hline 1125 & 21.953 & 27.880 \\
\hline F-test & $* *$ & ** \\
\hline LSD 0.05 & 0.293 & 0.225 \\
\hline LSD 0.01 & 0.428 & 0.329 \\
\hline \multicolumn{3}{|c|}{ 4. Interaction effects } \\
\hline $\mathrm{VxP}$ & $* *$ & $* *$ \\
\hline VXB & $* *$ & NS \\
\hline PXB & $* *$ & $* *$ \\
\hline V X P XB & $* *$ & $* *$ \\
\hline
\end{tabular}

Effect of boron fertilizer rates:

Data in Table (4) showed that there were significant differences in root yield. With expecting the effect of boron fertilizer effects on root yield, increasing its levels from 0 to $1.125 \mathrm{~kg} \mathrm{H}_{3} \mathrm{PO}_{4} \mathrm{fed}^{-1}$ tended to increase root yield from 20.966 to 21.953 and 24.968 to $27.880 \mathrm{Mg}$ fed $^{-1}$ in the two growing seasons. These findings may be attributed to boron plays an important function in sugar beet as maintaining the balance between sugar and starch; translocation of sugar and carbohydrates, standard cell division, nitrogen metabolism and protein formation, and cell wall configuration Also, it plays the main roles in the correct function of cell membranes and the transport of $\mathrm{K}^{+}$ to guard cells to the internal water balance control system they reported that Fertilizing sugar beet by mixture of potassium +Boron + Calcium recorded an important increase in root and extracted sugar yields/fed and sucrose $\%$ as compared to untreated. This findings are in the line with Bondok (1996); El-Hawary (1999) and Aly et al. (2017) they reported that Fertilizing sugar beet by mixture of potassium + Boron + Calcium recorded an important increase in root and extracted sugar yields/fed and sucrose $\%$ as compared to untreated.

The effect of interaction between cultivars and phosphorus fertilizer levels:

Data in Table 5 represents the cultivars $\mathrm{X}$ phosphorus fertilizer levels and stated their was a significant effect in both seasons. Cultivars Gloria when treated with the fifth phosphorus levels recorded the highest mean of root yield (29.839 $\left.\mathrm{Mg} \mathrm{fed}^{-1}\right)$. On contrary, cultivars Diamond with the highest mean of phosphorus fertilizer rates recorded the highest mean of root yield $\left(27.979 \mathrm{Mg} \mathrm{fed}^{-1}\right)$. These results were reported by Gobara and Mekki (2005).

Table 5. Effect of phosphorus and cultivars on suger beet root fresh weight $\left(\mathrm{Mg} \mathrm{fed}^{-1}\right)$

\begin{tabular}{|c|c|c|}
\hline \multirow{3}{*}{ Cultivars } & \multicolumn{2}{|c|}{ Phosphorus effects $\left(\mathrm{kg}_{2} \mathrm{O}_{5}\right.$ fed $\left.^{-1}\right)$} \\
\hline & 2014/2015 & $2015 / 2016$ \\
\hline & \begin{tabular}{|llll}
12 & 24 & 36 & 48 \\
\end{tabular} & $\begin{array}{llll}12 & 24 & 36 & 48 \\
\end{array}$ \\
\hline Diamond & 15.3618 .921 .0323 .427 .98 & 17.0321 .7826 .4630 .3133 .4 \\
\hline Gloria & 15.1817 .620 .852429 .84 & 18.1524.2227.1630.7634.9 \\
\hline F-test & ** & ** \\
\hline LSD 0.0 & 0.463 & 0.356 \\
\hline LSD 0.01 & 0.676 & 0.52 \\
\hline
\end{tabular}

Regarding to the interaction between phosphorus and boron, data in Table 6 illustrate a significant differences and the highest root yield (32.86 and $36.27 \mathrm{Mg}$ $\left.\mathrm{fed}^{-1}\right)$ in the first and second seasons, respectively were recorded from $48 \mathrm{~kg} \mathrm{P}_{2} \mathrm{O}_{5}$ and 1.125 boron $\mathrm{kg} \mathrm{fed}^{-1}$.

Table 6. Effect of phosphorus and boron treatments on root fresh weight $\left(\mathrm{Mg} \mathrm{fed}^{-1}\right)$

\begin{tabular}{|c|c|c|c|c|c|c|}
\hline \multirow{3}{*}{ 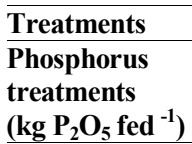 } & \multicolumn{6}{|c|}{ Boron effects $\left(g\right.$ fed $\left.^{-1}\right)$} \\
\hline & \multicolumn{3}{|c|}{$2014 / 2015$} & \multicolumn{3}{|c|}{ 2015/2016 } \\
\hline & $\mathbf{0}$ & 750 & 1125 & $\mathbf{0}$ & 750 & 1125 \\
\hline 0 & 13.71 & 15.4 & 16.73 & 15.9 & 17.51 & 19.4 \\
\hline 12 & 17.13 & 18.4 & 19.32 & 21.5 & 23.28 & 24.2 \\
\hline 24 & 19.86 & 20.9 & 22.06 & 25.5 & 26.91 & 28.06 \\
\hline 36 & 23.23 & 23.7 & 24.21 & 29.6 & 30.58 & 31.48 \\
\hline 48 & 25.34 & 28.5 & 32.86 & 32.5 & 33.75 & 36.27 \\
\hline F-test & \multicolumn{3}{|c|}{$* *$} & \multicolumn{3}{|c|}{$* *$} \\
\hline LSD 0.05 & \multirow{2}{*}{\multicolumn{3}{|c|}{$\begin{array}{l}0.201 \\
0.294\end{array}$}} & \multicolumn{3}{|c|}{0.2} \\
\hline LSD 0.01 & & & & \multicolumn{3}{|c|}{0.291} \\
\hline
\end{tabular}

There were significant differences between the triple interactions between all treatments on root fresh weight.

Root diameter (cm)

The effect of varietal effects, phosphorus fertilizer treatments, boron effects on root diameter $(\mathrm{cm})$ during 2014/2015, 2015/2016 seasons are presented in Table 7.

Root diameter exhibited significant differences in varietal effects in the two seasons. The thickest roots were produced from planting Diamond cultivar, results were 12.74 and $14.29 \mathrm{~cm}$ in the first, second and seasons, respectively. Whereas, the thinnest roots (11.98 and 14.09 $\mathrm{cm}$ ) came out from Gloria cultivar in the two seasons.

The trend of these results is similar to those of root length and similar discussion could be cited. These differences in response could be attributed to the genetic makeup of the cultivars that controls assimilate distribution within the plants. Confirming these findings with ElKammash et al. (2011) and Ali et al. (2012). Phosphorus 
fertilizer treatments had a significant effect on root diameter in the two growing seasons of this research. Roots in the treatment of $48 \mathrm{~kg} \mathrm{P}_{2} \mathrm{O}_{5} \mathrm{fed}^{-1}(14.61$ and $16.36 \mathrm{~cm})$ were significantly thicker than other treatments in the first, second and third seasons, respectively. Also, it can be noticed that $36 \mathrm{~kg} \mathrm{P}_{2} \mathrm{O}_{5}$ treatment came in the second rank after aforementioned treatment with respect root diameter in all seasons. It can be cited that the increase in root diameter due to the same reason that led to the increase in root length as previously mentioned.

These results are in full accordance with those reported Abo-El-Goud (2000); Seadah (2012) and Abdou et al. (2014)

Increasing boron fertilizer levels from 0 to 0.750 and $1.125 \mathrm{~kg} \mathrm{fed}^{-1}$ (Borax) tended to increase root diameter from 11.87 to 12.35 and 12.85 in the first season and 13.69 to 14.22 and $14.67 \mathrm{~cm}$ in the second one. These findings are accomplished with those observed by the enhancing effect root diameter may be attributed to the increase in cell size and numbers as a result of the increasing division of cells as well as activating accumulation of metabolites in storage roots. These findings are accomplished with those recorded by Mekdad (2015); Dewedar et al. (2015) and Aly et al. (2017).

Table 7. Effect of cultivars, phosphorus and boron treatments on sugerbeet plant root diameter (cm)

\begin{tabular}{|c|c|c|}
\hline \multirow{2}{*}{$\begin{array}{l}\text { Characters } \\
\text { Treatments } \\
\end{array}$} & \multicolumn{2}{|c|}{ Root diameter } \\
\hline & $2014 / 2015$ & $2015 / 2016$ \\
\hline \multicolumn{3}{|l|}{ 1. cultivar effects: } \\
\hline Diamond & 12.74 & 14.29 \\
\hline Galoria & 11.98 & 14.09 \\
\hline F-test & $* *$ & $* *$ \\
\hline \multicolumn{3}{|c|}{ 2. Phosphorus effects $\left(\mathrm{kg} \mathrm{P}_{2} \mathrm{O}_{5}\right.$ fed $\left.^{-1}\right)$} \\
\hline 0 & 9.51 & 12.07 \\
\hline 12 & 11.63 & 13.29 \\
\hline 24 & 12.64 & 14.17 \\
\hline 36 & 13.39 & 15.07 \\
\hline 48 & 14.61 & 16.37 \\
\hline$\overline{\text { F-test }}$ & $* *$ & $* *$ \\
\hline LSD 0.05 & 0.17 & 0.14 \\
\hline LSD 0.01 & 0.25 & 0.20 \\
\hline \multicolumn{3}{|c|}{ 3. Boron effects $\left(\mathrm{g} \mathrm{fed}^{-1}\right)$} \\
\hline 0 & 11.87 & 13.69 \\
\hline 750 & 12.35 & 14.22 \\
\hline 1125 & 12.85 & 14.67 \\
\hline F-test & $* *$ & $* *$ \\
\hline LSD 0.05 & 0.16 & 0.09 \\
\hline LSD 0.01 & 0.11 & 0.13 \\
\hline \multicolumn{3}{|l|}{ 4. Interaction effects } \\
\hline $\mathrm{VxP}$ & $* *$ & $*$ \\
\hline VXB & $* *$ & NS \\
\hline PXB & $* *$ & $* *$ \\
\hline VXBXP & $* *$ & $* *$ \\
\hline
\end{tabular}

Effect of interactions:

The interactions between all treatments had a significant effect on root diameter in the two seasons (Table 8). Mohamed. Y. H. and M.A.T. Yasin (2013) came to similar results. Regarding to phosphorus fertilizer and boron combination had a significant effect. Using 48 $\mathrm{kg} \mathrm{P}_{2} \mathrm{O}_{5}$ and $1.125 \mathrm{~kg}$ borax gave the highest mean in the two season. While, the lowest mean could be observed from control treatment.

Sucrose percentage $(\%)$ :

The effect of cultivars, phosphorus, boron and their interaction on sucrose \% during 2014/2015 and 2015/2016 seasons are registered in Table 8.

Table 8 . Effect of cultivars, phosphorus and boron treatments on sugerbeet plant Sucrose percentage (\%)

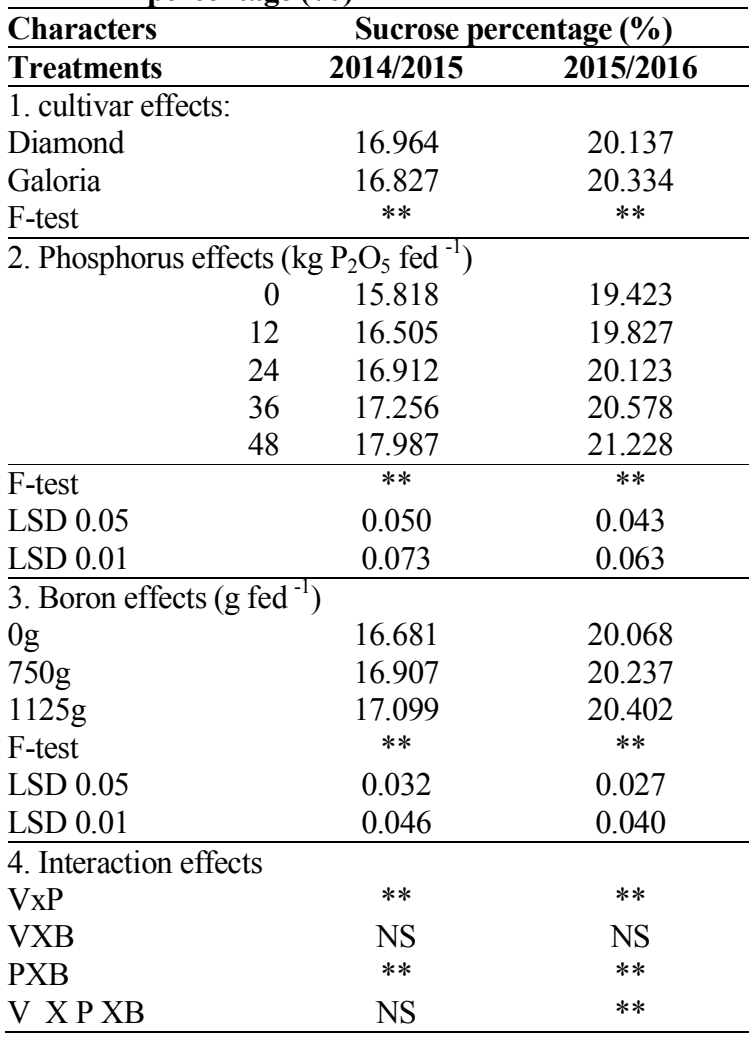

According to the analysis of variance of obtained data, it can be stated that varietal effects of sugar beet significantly affected sucrose $\%$ in the two seasons. Generally, it can be concluded that cultivars of beets showed a significant increase in sucrose \% and produced the highest values, which data were 16.96 from cultivars diamond in the $1^{\text {st }}$ season and 20.33 from cultivars Gloria in the $2^{\text {nd }}$ season. The favorable effect of cultivars of sugar beet might be backed to genetic effects. Similar results are pertinence with those ElSheikh et al. (2009) and Aly et al. (2012).

As shown from data collected in Table8, phosphorus fertilizer treatments had a significant effect on sucrose $\%$ in all growing seasons. Phosphorus caused a significant increase in sucrose $\%$ over all treatments and induced the highest values i.e. 17.98 and $21.23 \%$ in the first and second seasons, respectively. The lowest means of sucrose content in roots $(15.82 \%$ and $19.42 \%$ in the first and second seasons, respectively) were obtained on account of control treatment (without fertilization) in the first and second seasons season. It can be suggested that this increase in sucrose \% may be reflected the role of phosphorus in improving growth and dry matter accumulation by increasing the uptake and availability of most nutrients, consequently enhancement sucrose content 
in roots. Abdou et al. (2014) and El-Mansoub et al. (2014) suggested similar results.

Boron fertilizer treatments had a significant effect on sucrose \% in all growing seasons. Increasing boron fertilizer levels from 0 to 0.750 and $1.125 \mathrm{~kg}$ Borax/fed tended to increase sucrose \% from 16.68 to 16.90 and 17.09 in the first season and 20.07, 20.24 and $20.40 \%$ in the second season. The stimulation effects of micronutrients on quality traits may be attributed to the increase in sucrose $\%$. Boron is essential for the formation of new cells in meristems in addition to a vital role in sugar translation to roots. Similar trend was obtained by Ab elaal et al. (2015) and Aly et al. (2017).

Regarding the effect of all treatments interactions on sucrose \%, it was significant in the two growing seasons. The highest values of sucrose \% (18.21 and $21.59 \%$ ) resulted from utilizing phosphorus in the high rates besides in the third boron application in the first and second seasons, respectively. On the other hand, the lowest ones were obtained by no application of phosphorus or boron in all seasons.

Total fresh Yield:

Total fresh weight of sugar beet plants data $(\mathrm{Mg}$ $\mathrm{fed}^{-1}$ ) as affected by cultivars, phosphorus, boron treatments during 2014/2015 and 2015/2016 seasons are presented in Table 9. Cultivars had a significant effect on total yield and Gloria variety surpassed Diamond variety of total fresh weight $(30.724,36.967$ and $28.448,35.855 \mathrm{Mg}$ $\mathrm{fed}^{-1}$ ) in the first and second seasons, respectively. The superiority of total yield may be due to these increment in root yield might be due to the differences among sugar beet varieties under study due to the variation in the genes makeup and their response to the environmental condition. These results are in harmony with those obtained by ElSheikh et al. (2009) and Hanan Y. Mohamed and M.A.T. Yasin (2013).

On the other hand, the collected data in Table 9 show that there were remarkable significant differences among phosphorus treatments on total yield per feddan during the two growing seasons. Noteworthy, $48 \mathrm{~kg} \mathrm{P}_{2} \mathrm{O}_{5}$ was the best treatment among other phosphorus treatments, which resulted in the maximum total yield (38.258 and 46.406 $\mathrm{Mg} \mathrm{fed}{ }^{-1}$ ) in the first and second seasons, respectively. Addition of $36 \mathrm{~kg} \mathrm{P}_{2} \mathrm{O}_{5}$ ranked the second treatment for total yield which recorded 32.593 and 41.290 $\mathrm{Mg} \mathrm{fed}{ }^{-1}$ in the two seasons. This effect of phosphorus treatments expressly may be ascribed to share in the bioactivities inside plants and increases the creating of carbohydrates as starch and sugars. Moreover, It helps in the division of plant cells and shares in forming ATP (Adenosine triphosphate). Similar results were obtained by Abdou et al. (2008), they reported that increasing phosphorus fertilizer level from zero up to $30 \mathrm{~kg} \mathrm{P}_{2} \mathrm{O}_{5} \mathrm{fed}^{-1}$ markedly increased root weight $\mathrm{g} / \mathrm{plant}$.

With expecting the effect of boron fertilizer effects on total yield, increasing its levels from 0 to $1.125 \mathrm{~kg}$ $\mathrm{H}_{3} \mathrm{PO}_{4} /$ fed tended to increase root yield from 27.801 to 31.385 and 34.262 to $38.302 \mathrm{Mg}$ fed $^{-1}$ in the two growing seasons. These findings may be attributed that boron plays an important function in sugar beet as maintaining the balance between sugar and starch; translocation of sugar and carbohydrates, standard cell division, nitrogen metabolism and protein formation, and cell wall configuration. Also, it plays the main roles in the correct function of cell membranes and the transport of $\mathrm{K}^{+}$to guard cells to the internal water balance control system they reported that Fertilizing sugar beet by mixture of potassium plus Boron plus Calcium recorded a important increase in root and extracted sugar yields/fed and sucrose $\%$ as compared to untreated. These findings are in line with Aly et al. (2017) they reported that fertilizing sugar beet by a mixture of potassium plus Boron plus Calcium recorded an important increase in root and extracted sugar yields/fed and sucrose $\%$ as compared to untreated.

\section{Table 9. Effect of cultivars, phosphorus and boron treatments on sugarbeet plant total yield $\left(\mathrm{Mg} \mathrm{fed}^{-1}\right)(\%)$}

\begin{tabular}{|c|c|c|}
\hline \multirow{2}{*}{$\begin{array}{l}\text { Characters } \\
\text { Treatments }\end{array}$} & \multicolumn{2}{|c|}{ Total Yield (Mg fed $\left.{ }^{-1}\right)$} \\
\hline & $2014 / 2015$ & $2015 / 2016$ \\
\hline \multicolumn{3}{|c|}{ 1. Varietal effects: } \\
\hline Diamond & 28.448 & 35.588 \\
\hline Galoria & 30.724 & 36.967 \\
\hline F-test & $* *$ & $* *$ \\
\hline \multicolumn{3}{|c|}{ 2. Phosphorus effects $\left(\mathrm{kg} \mathrm{P}_{2} \mathrm{O}_{5} \mathrm{fed}^{-1}\right)$} \\
\hline 0 & 22.080 & 24.771 \\
\hline 12 & 25.746 & 32.133 \\
\hline 24 & 29.251 & 36.787 \\
\hline 36 & 32.593 & 41.290 \\
\hline 48 & 38.258 & 46.406 \\
\hline F-test & $* *$ & $* *$ \\
\hline LSD 0.05 & 0.469 & 0.474 \\
\hline LSD 0.01 & 0.684 & 0.693 \\
\hline \multicolumn{3}{|c|}{ 3. Boron effects $\left(\mathrm{g} \mathrm{fed}^{-1}\right)$} \\
\hline 0 & 27.801 & 34.262 \\
\hline 750 & 29.557 & 36.267 \\
\hline 1125 & 31.385 & 38.302 \\
\hline F-test & $* *$ & $* *$ \\
\hline LSD 0.05 & 0.296 & 0.300 \\
\hline LSD 0.01 & 0.433 & 0.438 \\
\hline \multicolumn{3}{|c|}{ 4. Interaction effects } \\
\hline $\mathrm{VxP}$ & $* *$ & $*$ \\
\hline VXB & $* *$ & NS \\
\hline PXB & $* *$ & $* *$ \\
\hline VXBXP & $*$ & $* *$ \\
\hline
\end{tabular}

The interaction between cultivars and phosphorus fertilizer levels showed a a significant effect in the two seasons. Gloria cultivars which treated with phosphorus at the rate of $48 \mathrm{~kg} \quad \mathrm{p}_{2} \mathrm{O}_{5} \mathrm{fed}^{-1}$, recorded the highest mean of total yield (38.532 $\left.\mathrm{Mg} \mathrm{fed}^{-1}\right)$. the These results were reported by Gobarah and Mekki (2005) and Aly et al. (2017).

Related the interaction between cultivars and boron there were significant differences and Gloria cultivars with boron at a rate of $1.125 \mathrm{~kg} \mathrm{fed}^{-1}$ recorded $32.289 \mathrm{Mg} \mathrm{fed}^{-1}$ in the first season while, Diamond cultivars with untreated treatment achieved $26.412 \mathrm{Mg} \mathrm{fed}^{-1}$

concerning to the interaction between phosphorus and boron, there were significant differences in the second season Table (10). The highest total yield/fed (42.402 Mg $\mathrm{fed}^{-1}$ ) in the first season, respectively recorded from $48 \mathrm{~kg}$ $\mathrm{P}_{2} \mathrm{O}_{5}$ and 1.125 boron $\mathrm{kg} \mathrm{fed}^{-1}$. 
Table 10 . Effect of the interaction between phosphorus and boron treatments on sugarbeet plant total yield $\left(\mathrm{Mg} \mathrm{fed}^{-1}\right)(\%)$

\begin{tabular}{|c|c|c|c|c|c|c|}
\hline \multicolumn{7}{|c|}{ Total Yield (Mg fed $\left.{ }^{-1}\right)$} \\
\hline \multirow{3}{*}{$\begin{array}{l}\text { Treatments } \\
\text { Phosphorus } \\
\text { treatments } \\
\left(\mathrm{kg} \mathrm{P}_{2} \mathrm{O}_{5} \text { fed }^{-1}\right)\end{array}$} & \multicolumn{6}{|c|}{ Boron effects $\left(\mathrm{g} \mathrm{fed}^{-1}\right)$} \\
\hline & \multicolumn{3}{|c|}{$2014 / 2015$} & \multicolumn{3}{|c|}{$2015 / 2016$} \\
\hline & $\mathbf{0}$ & 750 & 1125 & $\mathbf{0}$ & 750 & 1125 \\
\hline 0 & 20.182 & 22.235 & 23.740 & 15.858 & 17.513 & 19.398 \\
\hline 12 & 24.410 & 25.793 & 27.035 & 21.522 & 23.273 & 24.192 \\
\hline 24 & 28.022 & 29.210 & 30.522 & 25.452 & 26.905 & 28.058 \\
\hline 36 & 31.908 & 32.642 & 33.228 & 29.557 & 30.583 & 31.478 \\
\hline 48 & 34.485 & 37.903 & 42.402 & 32.452 & 33.745 & 36.265 \\
\hline F-test & & ** & & & ** & \\
\hline LSD 0.05 & & 0.219 & & & 0.216 & \\
\hline LSD 0.01 & & 0.341 & & & 0.336 & \\
\hline
\end{tabular}

There were significant differences between the triple interactions between all treatments in the second season.

\section{CONCLUSION}

It could be concluded that all used treatment significantly affected on sugar beet yield and its component. The interaction between Gloria cultivars, phosphorus fertilizer at the rate of $48 \mathrm{~kg} \mathrm{P}_{2} \mathrm{O}_{5} \mathrm{fed}^{-1}$, boron at the rate of $1.125 \mathrm{~kg} \mathrm{fed}^{-1}$ recorded the best in all used treatments.

\section{REFERENCES}

Abo-El-Goud,sh.A.M (2000). Studies on fodder beet.Pn.D.thesis, Fac.of Agric.Mansoura University

Abdou, M.A. ; N.M.M. Awad and E.H.H. Selim (2008). Effect of ploughing and phosphorus fertilizer levels on sugar beet productivity and quality. J. Agric. \& Env. Sci., Alex Univ., Egypt, 7(2): 1-11.

Abdou, M.A. ; N.M.M. Awad and M.E.M. Ibrahim (2014). Influence of ploughing depth, phosphorus fertilizer level and thinning date on sugar beet productivity and quality. J. Plant Production, Mansoura Univ., 5(12): $2037-2045$

Ali I.F.A. (2000). Factors affecting yield of some sugar beet varieties in newly reclaimed soils. M. Sc. Thesis, Fac. Agric., Cairo Univ., Egypt.

Aly, E. F. A.; A. H. S. A. Al-Labbody; M. E. R. Mekkei and E. A.M. El Haggan (2012). Effect of hill spacing and cease irrigation before harvesting on some sugar beet varieties under sandy soils. J. Plant Production, Mansoura Univ., 3 (6): 1039 1047.

Armin, M. and M.R. Asgharipour (2012). Effect of time and concentration of boron foliar application on yield and quality of sugar beet. Am. Eur. J. Agric. Environ. Sci., 12(4): 444-448.

Azzazy N.B.,N.M.S. Shalaby. and A.M. Abd El-Razek (2007). Effect of planting density and days to harvest on yield and quality of some sugar beet varieties under Fayoum Governorate condition. Egypt J.of Appl. Sci., 22 (12A): 101-114.

Black, C.A. (1965) "Methods of Soil Analysis". Part I, American Society of Agronomy. Madison, Wisconsin, USA.
Bondok, M.A., (1996). The role of boron in regulating growth, yield and hormonal balance in sugar beet(Beta vulgaris, var. vulgaris). Annal. Agric. Sci. Ain. Shams Univ., Cairo, Egypt 41: 15-33

Dewdar, M. D.H.; M.S.S. Abbas; EL. I. Gaber and H.A. Abd El-Aleem (2015). Influence of time addition and rates of boron foliar application on growth, quality and yield traits of sugar beet. Int. J. Curr. Microbiol. App.Sci., 4(2): 231-238

El-Kammash, T. N.; M. M. Abdelkader; M. A. Farag; E. A. Teama and A. M. Abou-Salama (2011). Evaluation of some newly introduced sugar beet cultivars under Egyptian north-delta conditions: IYield and yield components. J. Plant Production, Mansoura Univ., 2 (4): 535 - 545.

El-Mansoub, M. M. A. and H.Y. Mohamed (2014). Effect of sowing dates and phosphorus fertilizer on root rot and quality of some sugar beet varieties. j. plant production, Mansoura univ., vol. 5 (5): 745 764,2014

El-Sheikh S.R.E., Khaled K.A.M. and Enan S.A.A.M. (2009). Evaluation of some sugar beet varieties under three harvesting dates. J. Agric. Sci. Mansoura Univ., 34 (3): 1559-1567.

Gomez, K.A. and A.A. Gomez, (1984). Statistical procedures for agricultural research (2 ed.). John Wiley and sons, NewYork, p. 680

Hussain, Z.; R.A. Khattak; M. Irshad.and Q. Mahmood (2014). Sugar beet (Beta vulgaris L.) response to diammonium phosphate and potassium sulphate under saline-sodic condition. British Society of Soil Science, 1-10.

Ismail, A.M.A. and R.A. Abo El-Ghait (2004). Effect of balanced fertilization of NPK on yield and quality of sugar beet. Egypt. J. of Agric. Res., 82 (2): 717 729.

Ismail, A.M.A.; A.H.S. AL-Labbody and N.M.S. Shalaby (2007).Evaluation of some sugar beet varieties under different combinations of NPK fertilizers. Egypt. J. of Appl. Sci., 22(3): 77-90.

Marinković, B. ; J. Crnobarac ; G. Jaćimović ; D. Marinković ; D.V. Mircov and M. Rajici (2008). Importance of increasing amounts of NPK nutrients on sugar beet yield. Res. J. of Agric. Res., 40 (2): 99-104.

Mehanna, H.M., Safi-naz S. Zaki and Hussien, M.M. (2017). Influences of Irrigation and Fertilizer on Growth and Yield of Two Sugar Beet varieties in Egypt. Middle East Journal of Agriculture, 6(1012):

Mekdad, A. A. Ali (2015). Sugar Beet Productivity As Affected By Nitrogen Fertilizer and Foliar Spraying With Boron. J. Curr. Microbiol. App. Sci., 4(4): 181-196.

Gobarah .E.M. and B.B. Mekki (2005). Influence of Boron Application on Yield and Juice Quality of Some Sugar Beet Cultivars Grown under Saline Soil Conditions. Journal of Applied Sciences Research 1(5): 373-379.

Ouda, S. M.M. (2007). Effect of chemical and bio-fertilizer of nitrogen and boron on yield and quality of sugar beet. Zagazig J. Agric. Res., 34: 1-11. 
Seadh, S.E. (2012). Maximizing sugar beet yield with decreasing mineral fertilization pollution. Int. J. of Agric. Sci., 4 (7): 293-298.

Shalaby, N.M. (1998). Effect of different nitrogen levels and the period of no irrigation before harvesting on yield and quality of sugar beet. M. Sc. Thesis, Fac. of Agric., AL-Azhar Univ.

Shalaby, N.M.E; A.M.H. Osman and A.H.S.A. ELLabbody (2011). Relative performance of some sugar beet varieties under three plant densities in newly reclaimed soil. Egypt, J. Agric., Res., 89 (1).

Soliman, M. E.; M.M.A. Hammada and A.E. Abd El-Nabi (2014). Response of sugar beet plants to different compost types and boron spraying and their effect on growth characters and quality under Ras sudr conditions. J. Soil Sci. and Agric. Eng., Mansoura Univ.,. 5 (10): 1363 - 1375.

Osman, A.M.H. (2005). Influence of nitrogen and potassium fertilization on yield and quality of two sugar beet varieties. Egypt. J. Agric. Res., 83 (3): 1237-1254.

Mohamed . Y. H. and M.A.T. Yasin (2013).Response of Some Sugar Beet Varieties toHarvesting Dates and Foliar Application of Boron and Zinc in Sandy Soils J. Agron. Zagazig Univ35, No. 2, pp. 227252.
Abdelaal, Kh.A.A.; Shimaa, A. Badawy and Shahrzd, M.M.Neana (2015). Effect of foliar application of microelements and potassium levels on growth, physiological and quality characters of sugar beet (beta vulgaris 1.) under newly reclaimed soils $J$. Plant Production, Mansoura Univ., 6(1): 123 -133.

Aly, E. F. A. 1; Soha R. Khalil2 and Eman M. Abdel Fattah3 (2017) . Effect of Boron, Potassium and Calcium on Growth, Yield and Quality of Two Sugar Beet Varieties under Sandy Soil Conditions J. Plant Production, Mansoura Univ., 8(6): $699-$ 704.

Le-Docte, A. (1927). Commercial determination of sugar beet root using the Sachr Le-Doctaprocess. International Sugar J., 29: 488-492. (C.F. Sugar beet Nutrition, April, 1927Applied Sciences Publishers LTD, London, A.P. Draycott).

EL-Hawary, M.A. (1999). Influence of nitrogen, potassium and boron fertilizer levels on sugar beet under saline soil conditions. J. Agric. Sci. Mansoura Univ., 24(4): 1573-1581.

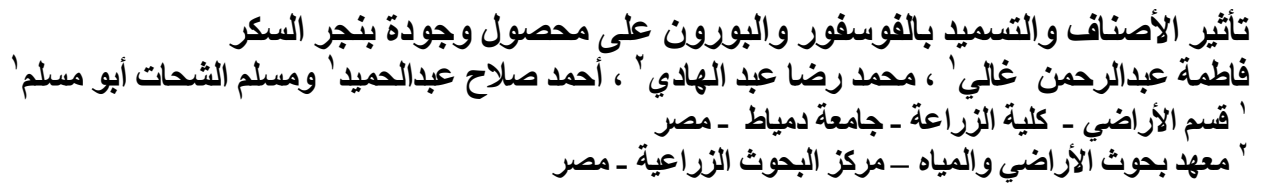

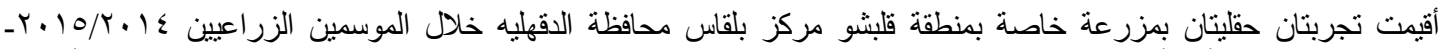

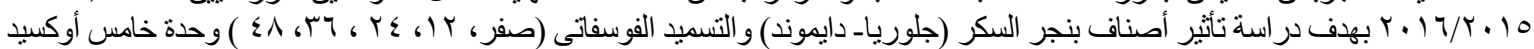

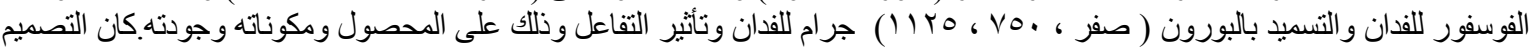

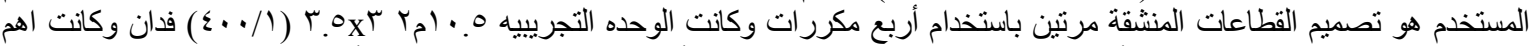

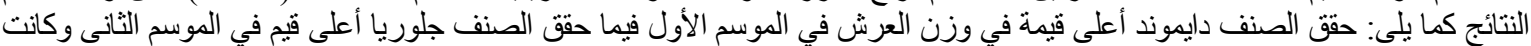

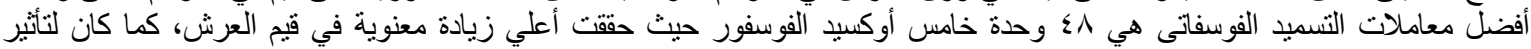

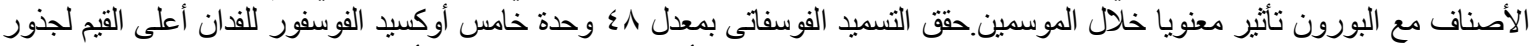

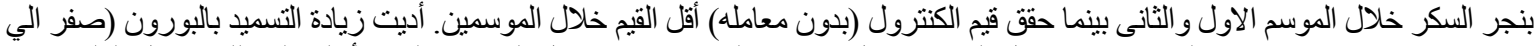

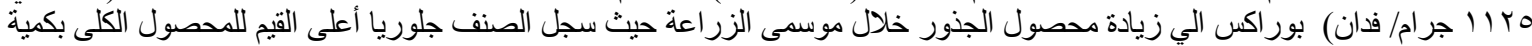

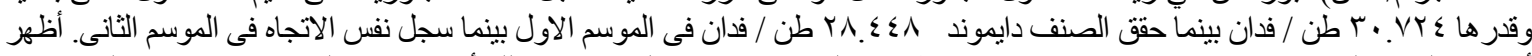

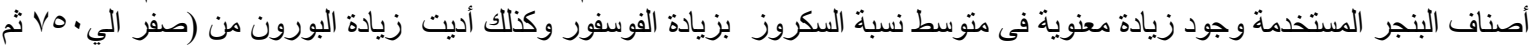

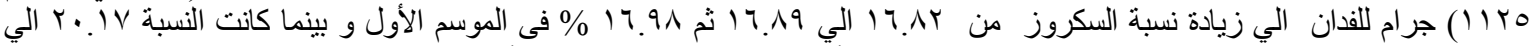

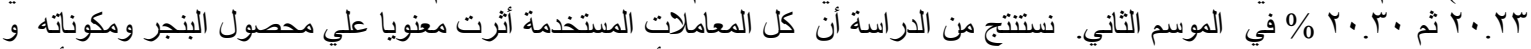

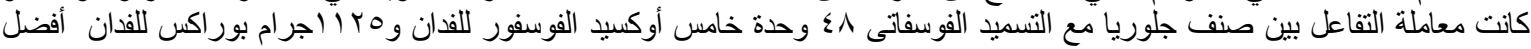
المعاملات المستخدمة لزيادة المحصول ومكونة انته علاوة على على نسبة السكر. 